\title{
Caribbean Writers and the Jewish Diaspora A Shared Experience of Otherness
}

\section{Bénédicte Ledent}

The parallel between the Jewish and the African diasporas is a traditional one in black America, established in the days of slavery, as testified by such famous spirituals as "Go Down, Moses" or "The Rivers of Babylon." As Julius Lester reminds us,

It was in the time of slavery that blacks discovered in the Christian Old Testament another enslaved people, the Jews. In the story of the Israelites in Egypt and their deliverance from bondage, black slaves found a mirror of their own situation. ${ }^{1}$

A similar line of thought underlay Rastafarianism, the popular religious movement initiated by the blacknationalist Jamaican Marcus Garvey in the 1930s. Its ideology, later publicized by Bob Marley with songs like "Exodus," relies heavily on the Old Testament, too, and regards Jamaicans as prisoners of Babylon -- the white colonial system -- from which they will eventually escape to reach the Promised Land, in their case the Ethiopia of Haile Selassie.

For all its pervasiveness in popular culture, the analogy between the black and the Jewish experiences of exclusion has not always been unproblematic, particularly in the USA. Whereas this alliance may have helped to galvanize the civil-rights movement in the 1960s, it has been regularly called into question, whether on racist grounds or for economic reasons. Without even taking Louis Farrakhan's patent antisemitism into account, the black/Jewish connection has been questioned in the States by such influential thinkers as Harold Cruse, in his essay The Crisis of the Negro Intellectual, ${ }^{2}$ and even by James Baldwin, who, in a piece called "The Harlem Ghetto," dwells on the tension between the two groups, what he calls "the Negro's ambivalent relation to the Jew." ${ }^{3}$ Indeed, Baldwin writes, if "Jews, like Negroes, must use every possible weapon in order to be accepted and must try to cover their vulnerability by a frenzied adoption of the customs of the country," ${ }^{4}$ in Harlem, the Jews are also

small tradesmen, rent collectors, real estate agents, and pawnbrokers; they operate in accordance with the American business tradition of exploiting Negroes, and they are therefore identified with oppression and are hated for it. $^{5}$

In Baldwin's view, therefore, the Jews and the blacks seem to have more reason to be enemies than partners.

In the English-speaking Caribbean, however, perhaps because of a less segregated social system but

\footnotetext{
${ }^{1}$ Julius Lester, "The Outsiders: Blacks and Jews and the Soul of America," Transition 68 (Winter 1995): 68.

${ }^{2}$ Harold Cruse, The Crisis of the Negro Intellectual (1967; New York: Quill, 1984).

${ }^{3}$ James Baldwin, "The Harlem Ghetto" (1948), in Baldwin, Notes of a Native Son (1955; London: Pluto, 1984$)$ : 66.

${ }^{4}$ Baldwin, "The Harlem Ghetto," 69.

5 "The Harlem Ghetto," 68.
} 
Published in The Cross-Cultural Legacy: Critical and Creative Writings in Memory of Hena Maes-Jelinek, ed. by Gordon Collier, Geoffrey V. Davis, Marc Delrez and Bénédicte Ledent (Leiden \& Boston: Brill/Rodopi, 2017), pp. 201-218.

Status: Postprint (Author's version)

also because the Jewish population there is smaller and mostly arrived in the area well before the twentieth century, the links between the two diasporas have not given rise to such a heated debate as in the USA. They seem, rather, to have inspired creative writers extensively. Admittedly, as Sue Greene points out, the Jew's archetypal homelessness has sometimes been used as "a handy means for exploring and expressing the whole problem of [West Indian] identity or some part of it." ${ }^{6}$ In other words, she argues, "instead of depicting the Jew for his own sake, West Indian novelists tend to use him to illuminate some non-Jewish aspect of West Indian life." ${ }^{7}$ This charge might be true of some novels -- for example, V.S. Naipaul's The Mimic Men (1967) and its minor character Mr. Shylock, who may have been introduced just to highlight "the dominant theme of estrangement." 8 Yet, I would not be as pessimistic as Greene, for there is in many cases sincere sympathy, empathy even, on the part of postwar Caribbean writers -- not only with Jewish people's experience of displacement but also of oppression and extermination, which is indeed close to what the West Indians went through, as suggested in much of Wilson Harris's visionary prose, in particular his apocalyptic novel Jonestown (1996). ${ }^{9}$ One of the examples discussed by Greene in the above-mentioned article is John Hearne's novel Land of the Living (1961). Its main character is a Jewish refugee from Germany, Stefan Mahler, whose parents and sister were killed in the Nazi camps. After the war, Stefan relocates to the fictional island of Cayuna, where he meets Marcus Heneky, the leader of the Pure Church of Africa Triumphant, which is linked to a back-to-Africa group called 'Sons of Sheba'. It is true that there is something artificial about the characterization of both Stefan and Marcus, who can to some extent be viewed as archetypes of their own community. Yet the novel suggests a potentially fruitful comparison between two groups of people who have "been wounded in the same accident." 10 This is bound to generate some "shared comprehension," ${ }^{11}$ even if Stefan cannot fully approve of the violence used by the black rebels. A similar interaction between blacks and Jews is suggested in Paule Marshall's The Chosen Place, the Timeless People (1969), a novel bringing together Afro-Caribbean characters and a white Jewish one, Saul Amron. For the latter, the Jewish heritage of suffering passed on by his mother

became the means by which he understood the suffering of others. It encompassed them all. It had even, suddenly, reached across the years to include within its wide meaning what he had just witnessed. ${ }^{12}$

What he had "just witnessed" is the continued exploitation of the inhabitants of an unnamed Caribbean island. A third and last introductory example of this parallel between blacks and Jews can be found in Derek Walcott's poetry, most notably in his oft-quoted piece "A Far Cry from Africa," where the poet comments on the Mau Mau rebellion in Kenya in the 1960s and speaks of so-called "savages, expendable as Jews,"13 thereby underlining the commodification shared by the two peoples.

This ethos of compassion with the Jewish experience seems to be even more markedly present in the

\footnotetext{
${ }^{6}$ Sue Greene, "The Use of the Jew in West Indian Novels," World Literature Written in English 26.1 (1986): 151. This reference to Sue Greene's essay as well as a few other points made in the present article also feature in Bénédicte Ledent, Caryl Phillips (Manchester: Manchester UP, 2002).

${ }_{8}^{7}$ Greene, "The Use of the Jew in West Indian Novels," 151.

8 "The Use of the Jew in West Indian Novels," 152.

${ }^{9}$ See Hena Maes-Jelinek, "'Tricksters of Heaven': Visions of Holocaust in Jonestown and Fred D'Aguiar's Bill of Rights," in Maes-Jelinek, The Labyrinth of Universality: Wilson Harris's Visionary Art of Fiction (Cross/Cultures 86; Amsterdam \& New York: Rodopi, 2006): 41937 .

${ }^{10}$ John Hearne, The Land of the Living (1961; New York: Harper \& Row, 1962): 114. I would like to thank Louis James for pointing out the relevance of this novel to me. On Hearne's novel in the context of black-Jewish relations, see also Sarah Phillips Casteel, "Calypso Jews: Holocaust Refugees in the Caribbean Literary Imagination," Holocaust Studies 19.2 (Autumn 2013): 1-26. Her essay also deals with Jamaica Kincaid's Mr. Potter, which, unlike Hearne's novel, emphasizes "estrangement over empathy" ("Calypso Jews," 22).

${ }^{11}$ Hearne, The Land of the Living, 266.

${ }^{12}$ Paule Marshall, The Chosen Place, the Timeless People (1969; London: Longman, 1970): 164.

${ }^{13}$ Derek Walcott, "A Far Cry from Africa" (1962), in Walcott, Collected Poems 1948-1984 (London: Faber \& Faber, 1992$)$ : 17.
} 
Published in The Cross-Cultural Legacy: Critical and Creative Writings in Memory of Hena Maes-Jelinek, ed. by Gordon Collier, Geoffrey V. Davis, Marc Delrez and Bénédicte Ledent (Leiden \& Boston: Brill/Rodopi, 2017), pp. 201-218.

Status: Postprint (Author's version)

work of the younger generation of anglophone Caribbean writers, who, significantly, live diasporic lives - mostly in the UK and the USA -- and have often turned to the painful history of their native societies, particularly slavery, to try and come to terms with their own feeling of difference. As we shall see, several of them address the possible convergences between the African and the Jewish conditions - in many cases through references to the Holocaust - sometimes in passing, at other times with more insistence, not to say a form of obsessiveness. Paul Gilroy argues in The Black Atlantic that such a process of mutual understanding between blacks and Jews can help in fathoming the mechanisms of modem racism, ${ }^{14}$ particularly when this reasoning engages with what Caryl Phillips, one of the writers examined later in this essay, has called "Europe's obsession with homogeneity, and her inability to deal with the heterogeneity that is - in fact - her natural condition." ${ }^{15}$

Admittedly, a comparative approach to Jewish and black victimization has occasionally been questioned, not only because, for some commentators, it risks negating the uniqueness of the Jewish experience, but also because, in some instances, empathy could be said to conceal an appropriative impulse. However, as Michael Rothberg has demonstrated, an "interaction of different historical memories" should be encouraged because, when used constructively, it involves a productive dynamic likely "to create new forms of solidarity and new visions of justice." ${ }^{16}$ It is therefore a potentially positive development if the trauma shared by the black and Jewish diasporas has recently been much commented on and interpreted in accordance with various rationales -for example, by Celia Britton, in terms of incarceration, ${ }^{17}$ or by Stef Craps, in terms of loss. ${ }^{18}$ My intention in the rest of this essay is to follow in the wake of these studies and to show, through a few selected examples, that contemporary Caribbean writers' inclusive exploration of black and Jewish suffering is part of their open-minded attempt, as artists with complex identities, to explore their own sense of otherness -- be it racial, cultural or, indeed, sometimes sexual -- and to eventually achieve a multifaceted vision of the world marked by an almost compulsive reluctance to espouse purity and simplification. This ontological complexity on the part of writers whose own racial identification is sometimes complicated might explain why their allusions to the Jewish Diaspora are not exempt from a certain sense of ambiguity or distance, which, as we will see, takes slightly different forms but prevents a straightforward correspondence of blackness with Jewishness.

I would like to start this brief survey with David Dabydeen, a writer of East Indian descent from Guyana now settled in Britain, whose novel A Harlot's Progress (1999), set in eighteenth-century London, resuscitates some of the marginalized characters from Hogarth's series of engravings -- which, Dabydeen reminds us, also "has an anti-Semitic slant."19 Among the figures represented in the second plate of the famous series, which is devoted to the life of a prostitute called Moll Hackabout, are a young servant of African descent, Mungo, and a wealthy Jewish merchant who is Moll's protector. ${ }^{20}$ Dabydeen gives them a life in his novel, which nonetheless focuses primarily on Mungo, who could in a sense be viewed as the harlot of the title. ${ }^{21}$ In England

\footnotetext{
${ }^{14}$ Paul Gilroy, The Black Atlantic: Modernity and Double Consciousness (London \& New York: Verso, 1993): 187-223.

${ }^{15}$ Caryl Phillips, "On 'The Nature of Blood' and the Ghost of Anne Frank," CommonQuest 3.2 (1998): 6.

${ }^{16}$ Michael Rothberg, Multidirectional Memory: Remembering the Holocaust in the Age of Decolonization (Stanford CA: Stanford UP, 2009):

3,5 .

${ }^{17}$ Celia Britton, "Exile, Incarceration and the Homeland: Jewish References in French Caribbean Novels," in Comparing Postcolonial

Diasporas, ed. Michelle Keown, David Murphy \& James Procter (Basingstoke: Palgrave, 2009): 149-67.

${ }^{18}$ Stef Craps, "Linking Legacies of Loss: Traumatic Histories and Cross-Cultural Empathy in Caryl Phillips's Higher Ground and The Nature of Blood," Studies in the Novel 40.1-2 (Spring \& Summer 2008): 191-202.

19 David Dabydeen, "David Dabydeen talks to Mark Stein," Wasafiri 29 (Spring 1999): 29.

${ }^{20}$ On this series of prints and on Hogarth in general, see David Dabydeen, Hogarth's Blacks: Images of Blacks in Eighteenth Century English Art (Manchester: Manchester UP, 1987).

${ }^{21}$ See Christine Pagnoulle, "David Dabydeen's A Harlot's Progress: Memories in Knots and Stays," in No Land, No Mother: Essays on David Dabydeen, ed. Kampta Karran \& Lynne Macedo (Leeds: Peepal Tree, 2007): 181-203.
} 
Published in The Cross-Cultural Legacy: Critical and Creative Writings in Memory of Hena Maes-Jelinek, ed. by Gordon Collier, Geoffrey V. Davis, Marc Delrez and Bénédicte Ledent (Leiden \& Boston: Brill/Rodopi, 2017), pp. 201-218.

Status: Postprint (Author's version)

he meets a Jewish doctor, Sampson Gideon, an ambiguous figure, both crook and Samaritan, with whom he immediately feels a kind of solidarity, despite their racial and social differences. At one point, Mungo decides to go and stay with Gideon, keen "to find a soulmate, two tribes in the same craft and storm that bring us to the same soil," even as he knows that he will also become the Jew's slave. ${ }^{22}$ As Mungo further points out, Gideon is "the only alien [he is] familiar with in the realm" ${ }^{23}$ and, in addition, the only person who "looks upon [him] not as a foreigner but as a fellow man." ${ }^{24}$ This sense of alliance is such that Mungo hears voices foretelling the destruction of the Jews, some of whom will be "shot in the head and shovelled into pits. [...] [Others] reserved as logs for the huge furnaces [...]. The rest [...] worked to death, or starved to death" ${ }^{25}$-- an apocalyptic vision conflating the Nazi and the slave holocaust ${ }^{26}$ Focusing as it does on the constructedness of all representation, Dabydeen's narrative is full of contradictions and uncertainties, which surely prevents the reader from idealizing the link that binds the Jew and the black slave in his novel. Nevertheless, a clear correlation is established between these two outsiders, who are both viewed in eighteenth-century England as "strange dirty creatures [...] that thrive in the creases between floorboards, in nooks and chinks, in the cracks that cheapen the richest porcelain" 27 and are thus a threat to the assumed purity of the country where they live. In this sense, then, the novel can be read, as Jutta Schamp does, as

a prism which captures, probes, and dismantles the intricate and multi-layered psychological construction and manifestation of eighteenth-century anti-Semitism and racism in Britain. ${ }^{28}$

Another striking, albeit indirect reference to the Jewish Holocaust is provided by London-based Lawrence Scott, a white creole from Trinidad, in his homo-erotic novel Aelred's Sin (1998). ${ }^{29}$ This book mainly takes place in the 1960s in Ashton Park monastery in Somerset and focuses on Jean Marc de la Borde, a young man from a Caribbean planter's family who has left his native island of Les Deux Isles to become a Benedictine novice in England, where he finds the demands of monastic life difficult to obey. Confronted again and again with his ambiguous distinctiveness -- not only as a white Creole but also as a homosexual -- Jean Marc embarks on a comprehensive imaginative exploration of "an ancestral past of pain," ${ }^{30}$ of a history which has been obliterated. This includes his own traumatic experience of homophobia in his native island, the tragic death of his mixed-race lover, as well as the harrowing life of Jordan - an African boy who was enslaved and abused in Ashton Park in the eighteenth century and with whom Jean Marc identifies. ${ }^{31}$ But the novel also contains some discreet allusions to the Holocaust, which surface at a remove, as it were, in the sections where Jean Marc's Jewish friends, Joe and Miriam, talk with his brother, Robert, who has come to England after his sibling's death

\footnotetext{
${ }^{22}$ David Dabydeen, A Harlot's Progress (London: Jonathan Cape, 1999): 251.

${ }^{23}$ Dabydeen, A Harlot's Progress, 253.

${ }^{24}$ A Harlot's Progress, 261.

${ }^{25}$ A Harlot's Progress, 253.

${ }^{26}$ See Elizabeth Kowaleski Wallace, "Telling Untold Stories: Philippa Gregory's $A$ Respectable Trade and David Dabydeen's $A$ Harlot's

Progress," Novel: A Forum on Fiction 33.2 (Spring 2000): 249.

${ }^{27}$ Dabydeen, A Harlot's Progress, 231.

${ }^{28}$ Jutta Schamp, "Transfiguring Black and Jewish Relations: From Ignatius Sancho's Letters and Olaudah Equiano's Interesting Narrative to

David Dabydeen's A Harlot's Progress," ARIEL: A Review of International English Literature 40.4 (October 2009): 20.

${ }^{29}$ Scott's later novel Night Calypso (2004), featuring a Jewish nun who is a refugee in Trinidad in the late 1930s, also testifies to his interest in the trauma shared by Caribbean and Jewish people.

${ }^{30}$ Lawrence Scott, Aelred's Sin (London: Allison \& Busby, 1998): 414.

${ }^{31}$ In an otherwise very favourable article on Scott's novels, Hena Maes-Jelinek questions the validity of the implied "parallel between the horrors of the slave-trade and the ostracism of homosexuality." For her, these two types of persecution cannot be put on a par, if only because of the different consequences that they had on their victims, even if Scott points out that homosexuals were also exterminated by the Nazis. See Maes-Jelinek, "Lawrence Scott's Caribbeanness: A Personal Reading of Witchbroom and Aelred's Sin," in Postcolonial Knitting: The Art of Jacqueline Bardolph, ed. Richard Corballis \& André Viola (Palmerston North: Massey University, School of English and Media Studies and CRELA, Université de Nice-Sophia Antipolis, 2000): 169.
} 
Published in The Cross-Cultural Legacy: Critical and Creative Writings in Memory of Hena Maes-Jelinek, ed. by Gordon Collier, Geoffrey V. Davis, Marc Delrez and Bénédicte Ledent (Leiden \& Boston: Brill/Rodopi, 2017), pp. 201-218.

Status: Postprint (Author's version)

and becomes transformed by his confrontation with various types of otherness. In these conversations we are reminded, for example, that the wearers of the pink triangles: i.e. the homosexual inmates of the concentration camps, suffered "systematic elimination," too, and therefore need memorials like the other victims of barbarity, whether caused by Nazism or by slavery. ${ }^{32}$ Scott's novel superimposes different stories of discrimination, which the author himself views as travelling texts that "speak to each other" ${ }^{33}$ and help the reader -- but also Robert -to understand the protagonist's radical difference. This juxtaposition of various sorts of victimization results in "a poetry of pain," ${ }^{34}$ whereby Jewish suffering seems to acquire a paradigmatic quality that is echoed in homophobic and racial persecution, but also sets in motion a process of remembrance which erects memory as a form of resistance to oppression of all kinds. As Alison Donnell rightly points out, this novel of reconciliation offers us a "model of compassion and empathic engagement," ${ }^{35}$ which can be called "transgressive" because it implies a connection that goes beyond barriers, be they racial or sexual. It makes possible "experiencing the elsewhereness of marginal identities," ${ }^{36}$ and consequently "[positions] Caribbean narrative [...] as another space from which tolerant identification can be achieved," ${ }^{37}$ an impression confirmed by the other texts discussed in this essay.

The Jamaican Michelle Cliff, who now lives in the USA, is another Caribbean author who refers to Jewishness in her writing, and repeatedly so. Clare Savage, the young light-skinned protagonist of her first novel, Abeng (1984), is obsessed with the Holocaust, all the more so as this tragedy is dismissed by her white father and her teachers, for whom "Jews were expected to suffer":

To endure. It was a fate which had been meted out to them because of their recalcitrance in belief, their devotion to their own difference. ${ }^{38}$

In reaction to this refusal to face the fact that Jews were victims, young Clare wants to understand "why these events had happened," ${ }^{39}$ as if the history of the Holocaust -- which is for Clare perhaps nearer and better documented than that of slavery -- had triggered off in her a process of wide-ranging reflection on death and human evil. In her quest for meaning -- which is bound to remain "beyond reach" ${ }^{40}$-- the young Jamaican is particularly fascinated by the figure of Anne Frank, with whom she identifies because the latter's life is marked, just like hers, by the madness of racial classification. ${ }^{41}$ What might also preoccupy Clare in her relation to Anne, as Judith Raiskin suggests, is the idea of "racial fraud": i.e. of passing or of "crossing boundaries that are conceived of as 'natural'," which could be seen as a means of survival as well as a form of betrayal. ${ }^{42}$ Through the figure of the famous Jewish girl, in other words, Clare reaches, "without knowing it, for an explanation of her

\footnotetext{
${ }^{32}$ Scott, Aelred's Sin, 174. The Holocaust might also be evoked in the novel through the motif of ashes, which reverberates in the name of the monastery, Ashton.

${ }^{33}$ Lawrence Scott, "'Extravagant Stangers': Contribution to a Round Table Discussion," in Bridges across Chasms: Towards a Transcultural Future in Caribbean Literature, ed. Bénédicte Ledent (Liège, L3 - Liège Language and Literature, 2004): 16.

${ }^{34}$ Scott, Aelred's Sin, 115

${ }^{35}$ Alison Donnell, Twentieth-Century Caribbean Literature: Critical Moments in Anglophone Literary History (London \& New York: Routledge, 2006): 212.

${ }^{36}$ Donnell, Twentieth-Century Caribbean Literature, 213.

${ }^{37}$ Twentieth-Century Caribbean Literature, 211.

${ }^{38}$ Michelle Cliff, Abeng (1984; New York: Plume, 1985): 70.

${ }^{39}$ Cliff, Abeng, 75.

${ }^{40}$ Abeng, 75.

${ }^{41}$ Blackness and Jewishness in the context of Jamaican society are also briefly brought together in Andrea Levy's Small Island. One of the novel's central characters is Gilbert Joseph, whose father is a Jew converted to Christianity. Gilbert decides to join the British Royal Air Force during the Second World War in order to "fight [the Nazi] master race theory," whereby he, as a black man, and his father, as a Jew, are described as "anthropoid": i.e. as "resembling a human but primitive, like an ape." Levy, Small Island (London: Review, 2004): 131,129. 42 Judith Raiskin, Snow on the Cane Fields: Women's Writing and Creole Subjectivity (Minneapolis \& London: U of Minnesota P, 1996): 194.
} 
Published in The Cross-Cultural Legacy: Critical and Creative Writings in Memory of Hena Maes-Jelinek, ed. by Gordon Collier, Geoffrey V. Davis, Marc Delrez and Bénédicte Ledent (Leiden \& Boston: Brill/Rodopi, 2017), pp. 201-218.

Status: Postprint (Author's version)

own life," ${ }^{43}$ learning, among other things, that, "just as Jews were expected to suffer in a Christian world, so were dark people expected to suffer in a white one." ${ }^{44}$ This correlation between the Jewish and the postcolonial condition pervades Cliff's writing, both her fiction and her non-fiction, and might be part of her exploration of "colorism" in Jamaican society, but also of her own identity-quest as a white-looking woman brought up in mostly black surroundings.

References to Jewishness and Nazism are present, for example, in Cliff's first collection of prose poems, The Land of Look Behind (1985). In one of its sections, she suggests a parallel between Jamaican creoles and Sephardic Jews who were "forced to pretend that they were Christians," thus to pass as 'whites'; ${ }^{45}$ she starts another chapter with a visit to Anne Frank's secret annexe and attempts a comparison between herself and the author of the famous diary in these words:

I was born later

not into this world.

The trees were not the same

The horrors not exact - but similar ${ }^{46}$

And she concludes another poem, significantly entitled "Europe Becomes Blacker," with the thought that "All those gypsies shoveled into ovens / Now they were dark people too," ${ }^{47}$ thereby putting the Nazi genocide in relation to the simultaneous extermination of 'dark' people, be they Roma or blacks. These three instances from The Land of Look Behind illustrate Cliff's method in approaching black and Jewish histories, which is to try and establish connections between apparently separate experiences and to retrieve from oblivion people and facts that have been expunged because they do not fit into what she has called, in her novel Free Enterprise (1993), "the official version" of history. ${ }^{48}$ One of the characters in this fiction is Rachel DeSouza, a Jew from Suriname, who lives in an American leper colony in the 1920s. There she is invited to tell a story, to take part in a "poor man's Decameron," ${ }^{49}$ along with other marginalized and usually silenced individuals, with whom she creates a form of kinship. In line with Cliff's radical agenda, Rachel's story speaks more of resistance and survival than of victimization, and tells how her people fled Spain under the Inquisition and crossed the Atlantic in the wake of Christopher Columbus, ${ }^{50}$ which is another way of associating the Jewish Diaspora with the New World, but also of demonstrating, as Myriam Chancy notes, "the importance of preserving connections across histories and of the need to break with silence in order to make those connections through storytelling." ${ }^{51}$

Cliff's references to the Jewish experience are part and parcel of her refusal to adhere to an imposed model of history, and her often blunt denunciation of the selectivity that presides over the transmission of historical facts. Cliff's interest in Jewish history is also unequivocally associated with her own sense of

\footnotetext{
${ }^{43}$ Cliff, Abeng, 72.

${ }^{44}$ Abeng, 77.

${ }^{45}$ Michelle Cliff, "If I Could Write This in Fire, I Would Write This in Fire," The Land of Look Behind (Ithaca NY: Firebrand, 1985$)$ : 71.

${ }^{46}$ Cliff, "A Visit to the Secret Annex," The Land of Look Behind, 104.

${ }^{47}$ Cliff, "Europe Becomes Blacker," The Land of Look Behind, 169.

${ }^{48}$ Michelle Cliff, Free Enterprise (1993; London: Penguin, 1995): 16.

${ }^{49}$ Cliff, Free Enterprise, 58.

${ }^{50}$ It is interesting to point out that on several occasions -- both in Abeng and in interviews -- Cliff has suggested that Columbus could have been Jewish, a fact which goes against the grain of received history and "complicates the 'discovery' myth and the impulse for exploration." Judith Raiskin, "The Art of History: An Interview with Michelle Cliff," Kenyan Review 15.1 (Winter 1993): 63. See also Cliff, Abeng, 66-67.

${ }^{51}$ Myriam J.A. Chancy, Searching for Safe Spaces: Afro-Caribbean Women Writers in Exile (Philadelphia P A: Temple U P, 1997$)$ : 177.
} 
Published in The Cross-Cultural Legacy: Critical and Creative Writings in Memory of Hena Maes-Jelinek, ed. by Gordon Collier, Geoffrey V. Davis, Marc Delrez and Bénédicte Ledent (Leiden \& Boston: Brill/Rodopi, 2017), pp. 201-218.

Status: Postprint (Author's version)

outsiderness. This is most vividly illustrated in "Sites of Memory,"52 an autobiographical account of her experience as a visiting professor at a German university. This clearly political text is made up of short sections, conveying in a very frank manner the author's reactions to her readings, the people she meets, and the places she visits while in Germany. What the reader gathers from Cliffs patchwork of impressions is the sense that this country is more interested in colonizing the Other, intellectually or otherwise, than in addressing its own Nazi past, of which she finds traces everywhere -- for example, in graffiti or, more notably, in the Jewish part of a cemetery, which is deserted yet full of the "resonance of ghosts. ${ }^{13}$ In this Judenfriedhof -- interestingly, close to the university, which is described by Cliff as an institution that appropriates otherness instead of welcoming it -Cliff comes upon a monument which, she writes, bears

the names of the Family Blatt, with their dates, and: opfer Auschwitz opfer Riga I touch the etched letters, feel the coldness of black stone, see myself in the polished granite. ${ }^{54}$

This meditative text full of awed respect for the victims of the Jewish genocide confirms that Cliff literally sees in the Holocaust a reflection of her own plight, which is, however, significantly refracted through the blackness of the slab, as if to indicate the intricacy of her own identity-quest. Cliff is clearly on the side of the living, and this enables her to protect the memory of the past, which she metaphorically does in her account by taking to a trash can "a plastic bag of empty beer cans and other garbage" ${ }^{55}$ that someone had left in the middle of the Jewish graves, testimony to the lack of deference of the locals.

This combined preoccupation with the Holocaust and the theme of otherness is also at the centre of Cliff's enigmatic short story entitled "A Woman Who Plays Trumpet Is Deported," ${ }^{56}$ an imaginative re-creation of the exceptional fate of Valaida Snow, a black American woman musician who, in the 1930s, goes to Europe in order to escape racism and, ironically, ends up in a concentration camp in Denmark in 1942, which, however, she will be able to leave alive. ${ }^{57}$ This narrative raises the issue of the black presence in Nazi camps, which some years ago was hotly debated in France with the publication of Serge Bilé's Noirs dans les camps Nazis. ${ }^{58}$ It also enables Cliff to attempt to verbalize what binds, and what distinguishes, blacks and Jews. At the end of the story, Cliff's heroine is waiting with other prisoners for a young Nazi to decide on their fate. While most of the people around her "deposit their valuables" on the "boy's table"59 -- being processed for death, one can assume -Valaida, who carries her horn under her arm, is singled out by the same young man, who asks her about Beethoven and Telemann, and, in doing so, humanizes her and possibly guarantees her survival. Significantly, Valaida is shown as standing in line with "women and girls and little children -- from which she is apart, yet of." ${ }^{100}$ This last phrase, "apart, yet of," is a concise expression of the protagonist's sense of simultaneous separation from and communion with the victims of the Holocaust -- in other words, of the tension that pervades any comparison between the black and the Jewish experiences, which are similar yet different.

Quite interestingly, these words -- "apart, yet of" -- remind one of another phrase, "of, and not of, this

\footnotetext{
${ }^{52}$ Michelle Cliff, "Sites of Memory," in Cliff, If I Could Write This in Fire (Minneapolis \& London: U of Minnesota P, 2008$)$ ) $49-63$.

${ }^{53}$ Cliff, "Sites of Memory," 60.

54 "Sites of Memory," 56.

55 "Sites of Memory," 56

${ }^{56}$ Michelle Cliff, "A Woman Who Plays Trumpet Is Deported," in Cliff, Bodies of Water (1990; London: Minerva, 1991): 55-60.

${ }^{57}$ Cliff's story is not the first fictional text to have been inspired by Snow; John Edgar Wideman, for example, wrote a story called "Valaida," included in his collection Fever (New York: Penguin, 1989). I would like to thank Kathleen Gyssels for pointing this out to me.

${ }^{58}$ Serge Bilé, Noirs dans les camps nazis (Paris: Serpent à plumes, 2005). The book contains a brief chapter on Valaida Snow.

${ }^{59}$ Cliff, "A Woman Who Plays Trumpet Is Deported," 60.

60 "A Woman Who Plays Trumpet Is Deported," 60.
} 
Published in The Cross-Cultural Legacy: Critical and Creative Writings in Memory of Hena Maes-Jelinek, ed. by Gordon Collier, Geoffrey V. Davis, Marc Delrez and Bénédicte Ledent (Leiden \& Boston: Brill/Rodopi, 2017), pp. 201-218.

Status: Postprint (Author's version)

place," which has been used by Caryl Phillips to define his own sense of multiple belonging, as a measure of his own strangeness, as it were. ${ }^{61}$ Born in St Kitts at the end of the 1950s, brought up and educated in Britain and now a New York resident, Phillips is the contemporary Caribbean writer who has explored the commonalities between the African and Jewish diasporas most extensively, and also most daringly. Indeed, while Dabydeen, Scott, and Cliff have tried to keep some visible distance (spatial, temporal, or other) between their black and Jewish characters, Phillips has gone so far as to adopt in some of his fictions the point of view of Jewish witnesses of the Holocaust. However, as critics such as Wendy Zierler, Stef Craps, and Michael Rothberg have pointed out, Phillips's special narrative methods, including fragmentation, indeterminacy, and intertextuality, have allowed him to steer clear of irresponsible appropriation and to challenge a simple equation between the black and Jewish experiences. ${ }^{62}$

It would be facile to trace Phillips's interest in Jewishness to his maternal grandfather, Emmanuel de Fraites, "a Jewish trader with Portuguese roots that reached back to the island of Madeira,"63 or even to his childhood in Leeds, a city with a large Jewish community, as Phillips reminds us in Foreigners. ${ }^{64}$ Yet, we know from the author's autobiographical essays and from some interviews that he learned about this Jewish ancestor only after his return to the Caribbean in the 1980s and that his fascination with Jewishness started earlier. It was part of his self-questioning as a black boy growing up in a Europe refusing to acknowledge the presence of the others in its midst. In The European Tribe, a travelogue in which the young writer examines his identity in the context of a tour around Europe, Phillips explains how,

as a child, in what seemed to me a hostile country, the Jews were the only minority group discussed with reference to exploitation and racialism, and for that reason, 1 naturally identified with them. [...] As a result I vicariously channelled a part of my hurt and frustration through the Jewish experience. ${ }^{65}$

And he concludes this passage with the striking words uttered by Frantz Fanon's philosophy professor and quoted in Black Skin, White Masks: "Whenever you hear anyone abuse the Jews, pay attention because he is talking about you." ${ }^{66}$ Further into The European Tribe, in a chapter entitled "Anne Frank's Amsterdam" in which Phillips discusses a visit to the famous Amsterdamer's house, he reveals how, when he was about fifteen, watching a television programme on the rounding-up of Jews during the Second World War triggered off in him his "first mature feelings of outrage and fear" ${ }^{67}$ and led to the writing of his first piece of fiction, a short story about a young Jewish boy in Amsterdam.

Obviously, this encounter with the history of the Jewish people had a profound effect on the young Phillips, not so much because he felt some sense of solidarity and connection with their victimization -- a feeling which was clearly there in the first place -- as, more importantly, because the awareness of the oppression suffered by the Jewish people started in the young artist, as was also the case for Cliff, an intricate process of

\footnotetext{
${ }^{61}$ Caryl Phillips, A New World Order (London: Secker \& Warburg 2001): 1-6.

${ }^{62}$ See Wendy Zierler, "'My Holocaust Is Not Your Holocaust': Facing Black and Jewish Experience in The Pawnbroker, Higher Ground and The Nature of Blood," Holocaust and Genocide Studies 18.1 (Spring 2004): 46-67; Craps, "Linking Legacies of Loss"; Rothberg, Multidirectional Memory, in particular 153-72.

${ }^{63}$ Phillips, A New World Order, 130; see also Renée Schatteman, "Disrupting the Master Narrative: An Interview with Caryl Phillips," Commonwealth 23.2 (Spring 2001): 99.

${ }^{64}$ Caryl Phillips, Foreigners: Three English Lives (London: Harvill Secker, 2007): esp. 211-15. In the "South Bank Show," broadcast on 13 April 2003, Phillips also tells Melvyn Bragg that one of the teachers who had a major influence on him at school was Mr Stern, who had escaped from Nazi Germany.

${ }^{65}$ Caryl Phillips, The European Tribe (London: Faber \& Faber, 1987): 54

${ }^{66}$ Phillips, The European Tribe, 54

${ }^{67}$ The European Tribe, 66.
} 
Published in The Cross-Cultural Legacy: Critical and Creative Writings in Memory of Hena Maes-Jelinek, ed. by Gordon Collier, Geoffrey V. Davis, Marc Delrez and Bénédicte Ledent (Leiden \& Boston: Brill/Rodopi, 2017), pp. 201-218.

Status: Postprint (Author's version)

reflection on human nature and evil which is still in progress today, as his prolific literary production testifies. Not only did Phillips's discovery of the Jewish experience cause him to interrogate himself "about the nature of history and the way people have convenient historical amnesia about it," ${ }^{68}$ it also brought him to ponder on issues of "difference and visibility" 69 which have plagued the black European community, too, and are also part of the Caribbean experience. When asked by an interviewer if he saw "any principal difference between the Jewish Diaspora and the Black one," Phillips recognized the following similarities:

you have two groups of people who, as a people, as a group of people, are scattered across the globe and maintain some kind of identity because of an accident of history. You also have two groups of people who have a very powerful sense of memory. A very powerful presentiment of loss.

At the same time, Phillips expresses his wariness of establishing theoretical parallels between the two experiences, because his focus, he insists, remains on the individuals. ${ }^{70}$ This is particularly true of his fiction, in which one can find several Jewish characters, most of whom are female -- perhaps a further indication of Phillips's special concern with otherness.

Two of Phillips's novels are especially relevant here -- Higher Ground (1989) and The Nature of Blood (1997). ${ }^{71}$ Even if much has already been written on them, it is still worth examining their characterization to see how it reflects the author's take on the black and Jewish experiences. Higher Ground is a novel in three parts, which deals with three displaced protagonists. Their stories, apparently separate, interconnect in many significant ways, not least thematically. While the first two sections present, respectively, an African interpreter who works for eighteenth-century slave traders and is eventually sold into slavery, and an African-American prisoner serving a sentence in a high-security prison in the 1960s, the last one focuses on Irina, a Jewish girl from Poland who has been sent to England by her parents to escape Nazism. Though a survivor, Irina is a tragic figure, for her life is spoiled by her obsessive and guilty remembrance of the past. In juxtaposing the stories of these three diasporic individuals trying to preserve their dignity, Phillips intimates similarities between the African and Jewish experience of isolation, displacement, and dislocation. This is even more clearly suggested when Irina meets Louis, a West Indian who is about to go back to his Caribbean home, even though their ultimate separation also evokes the characters' impossible union. Each individual fate is what matters in this novel. Nevertheless, the three stories are given more poignancy for being seen against each other, thereby illustrating one of Anne Frank's well-known utterances that "our lives are all different and yet the same." ${ }^{72}$

The Nature of Blood is the novel by Phillips that most visibly illustrates his preoccupation with the history of black and Jewish people and best testifies to his refusal to invest in abstract ideas at the expense of individual life stories and the ambiguity they entail. Focusing on several characters, some of whom are apparently unrelated, this novel is built around the notion of the ghetto -- whether racial, cultural, religious, or

\footnotetext{
${ }^{68}$ Monica Strauss, "Caryl Phillips and the Forum on Migration: Teaching the Value of Diversity," Aufbau 6 (23 March 2000$): 29$.

${ }^{69}$ Phillips, "On 'The Nature of Blood' and the Ghost of Anne Frank," 7.

${ }^{70}$ Lars Eckstein, "The Insistence of Voices: An Interview with Caryl Phillips" (1999), ARIEL: A Review of International English Literature 32.2 (April 2001): 39-40.

${ }^{71}$ However, brief references to Jewish characters can be found in other novels. This is the case with $A$ Distant Shore (2003), where a Dr Epstein tries to establish herself in an English village but does not "blend in," to borrow the words of the local publican. Caryl Phillips, $A$ Distant Shore (London: Secker \& Warburg, 2003), 9. Gordon Collier has convincingly demonstrated that Joyce, one of the characters in Phillips's Crossing the River (London: Bloomsbury, 1993), might be Jewish, too, and points out her resemblance to Irina in Higher Ground. See Collier, "Serene Surface, Secret Depths? Joyce's Section in Crossing the River" in Postcolonial Knitting: The Art of Jacqueline Bardolph, ed. Richard Corballis \& André Viola (Palmerston North: Massey University, School of English and Media Studies and CRELA, Université de Nice-Sophia Antipolis, 2000): 185-96

${ }^{72}$ Anne Frank, The Diary of Anne Frank (1947; London: Pan, 1974): 212.
} 
Published in The Cross-Cultural Legacy: Critical and Creative Writings in Memory of Hena Maes-Jelinek, ed. by Gordon Collier, Geoffrey V. Davis, Marc Delrez and Bénédicte Ledent (Leiden \& Boston: Brill/Rodopi, 2017), pp. 201-218.

Status: Postprint (Author's version)

national. As Phillips reminds us in an interview,

ghetto is an interesting word because it is a word in contemporary parlance which is almost universally associated with black people. But it's a word which emerged absolutely out of the Jewish experience. [...] the use of the word 'ghetto' is just one of the ways I try to show there is so much history which is very similar. Jewish people and black people are to some extent, I think, two great communities who exercise historical vigilance. They are always looking over their shoulder, always looking to the past, always hyperaware for obvious reasons of the fact that the present is conditioned by the past. ${ }^{73}$

The novel contains five main characters or groups of characters, whose stories constantly interweave and interrupt each other, unlike what happens in Higher Ground, where the three stories remain separate on paper, though not in the reader's mind. The Nature of Blood opens with Stephan Stern, a Jew from Germany, who from the 1930s participates in the underground efforts to build the state of Israel; then we meet his niece, Eva, who has survived the horrors of a concentration camp but finally commits suicide; then there is an Othello-like figure who lives in sixteenth-century Venice; followed by a group of Jews who are accused of causing the death of a young Christian boy in fifteenth-century Venice and are eventually burned at the stake; and, finally, Malka, a Jew from Ethiopia who suffers from racism in present-day Israel. ${ }^{74}$ The Nature of Blood is a complex text, but the bottom line of its masterful journey through time and cultures seems to be that humans have always attempted to define themselves by first defining the 'Other": i.e. by erecting walls and building ghettos. The originality of this novel resides in its undermining of this proclivity by performing what Claudia Sternberg has called a "blending of Jewish and postcolonial discourses, ${ }^{75}$ by which she means that the two are brought together to produce a new meaning. More concretely, this blending, or new meaning, takes the shape of Malka, the black Jew, the ultimate Other, in whom, as Sternberg points out, "the black and Jewish discourses are telescoped into one. ${ }^{76}$ This blending, however, does not mean that the two identities and experiences get diluted into each other. Through the character of Malka, the novel seems to plead for an opening of the two diasporas to each other rather than closure, which, Phillips suggests, is often operated by black and Israeli extremists alike. Clearly, by isolating themselves from each other, Jewishness and blackness take but one risk, that of sclerosis, as Phillips also forcefully suggests in The Atlantic Sound. In this travelogue, he visits a community of African Americans, the Hebrew Israelites, who have settled in the middle of the Negev desert -- a clear symbol of sterility -- and have established a "closed society" that walks "into the face of history" and thus seems to exclude any type of ambiguity. ${ }^{77}$

By contrast, Dabydeen, Scott, Cliff, and Phillips do not seem to be afraid to embrace the intricate fate that history has sent their way. If the early attempts to put blackness and Jewishness together - present in Rastafarianism, for example -- very much relied on an apparently integrative, yet ultimately dichotomous, epistemology that simply put the history of two peoples together or side by side, the quest of the younger writers of the Caribbean diaspora is based on a more convoluted perception of difference, which possibly better

\footnotetext{
${ }^{73}$ Phillips, "Disrupting the Master Narrative," 102

${ }^{74}$ For a sensitive take on the situation of Ethiopian Jews in Israel, see a film by Radu Mihaileanu, entitled Va, vis et deviens (Elzévir Films, France | Israel | Belgium | Italy 2005; 140 min.), which focuses on Schlomo, a young Ethiopian boy who is adopted by a white Jewish family living in Israel.

${ }^{75}$ Claudia Sternberg, "'We're Not Jews': Blending Postcolonial and Jewish Discourses in Contemporary British Literature," in Colonies, Missions, Cultures in the English-Speaking World: General and Comparative Studies, ed. Gerhard Stilz (Tübingen: Stauffenburg, 2001): 192.

${ }^{76}$ Sternberg, "'We're Not Jews'," 195.

${ }^{77}$ Caryl Phillips, The Atlantic Sound (London: Faber \& Faber, 2000): 220, 221.
} 
Published in The Cross-Cultural Legacy: Critical and Creative Writings in Memory of Hena Maes-Jelinek, ed. by Gordon Collier, Geoffrey V. Davis, Marc Delrez and Bénédicte Ledent (Leiden \& Boston: Brill/Rodopi, 2017), pp. 201-218.

Status: Postprint (Author's version)

corresponds to the world in which they live. In their writing, Jewish history seems to have kept its referential value as a paradigm of discrimination likely to promote thinking on otherness. But while this reflection still primarily turns on race and ethnicity, it is now often combined with a more visible interest in class, as illustrated by Dabydeen's A Harlot's Progress, or in gender and sexuality, as shown in Scott's Aelred's Sin. The four writers examined in this essay insist on the need to remember and re-examine the atrocities of former times -- including the Holocaust -- which is compounded in Cliff's writing by the urge to resist all systems of oppression and in Phillips's by the necessity to try and set up a dialogue among the victims of exclusion. As I have endeavoured to show, this historical, inclusive approach seems to offer the only hope of understanding but also getting rid of the ghettos inherited from the past.

\section{WORKS CITED}

Baldwin, James. "The Harlem Ghetto" (1948), in Baldwin, Notes of a Native Son (1955; London: Pluto, 1984): 57-72.

Bilé, Serge. Noirs dans les camps nazis (Paris: Serpent à plumes, 2005).

Britton, Celia. "Exile, Incarceration and the Homeland: Jewish References in French Caribbean Novels," in Comparing Postcoloniai Diasporas, ed. Michelle Keown, David Murphy \& James Procter (Basingstoke: Palgrave, 2009): 149-67.

Chancy, Myriam J.A. Searching for Safe Spaces: Afro-Caribbean Women Writers in Exile (Philadelphia PA: Temple UP, 1997).

Cliff, Michelle. Abeng (1984; New York: Plume, 1985).

------. "Europe Becomes Blacker," in Cliff, The Land of Look Behind (Ithaca NY: Firebrand,1985): 168-69.

------. Free Enterprise (1993; London: Penguin, 1995).

------. "If I Could Write This in Fire, I Would Write This in Fire," in Cliff, The Land of Look Behind, 57-76.

------. "Sites of Memory," in Cliff, If I Could Write This in Fire (Minneapolis \& London: U of Minnesota P, 2008$)$ ) $49-63$.

"A Visit to the Secret Annex," in Cliff, The Land of Look Behind, 104-107.

"A Woman Who Plays Trumpet Is Deported," in Cliff, Bodies of Water (1990; London: Minerva, 1991): 55-60.

Collier, Gordon. "Serene Surface, Secret Depths? Joyce's Section in Crossing the River," in Postcolonial Knitting: The Art of Jacqueline Bardolph, ed. Richard Corballis \& André Viola (Palmerston North: Massey University, School of English and Media Studies and CRE LA, Université de Nice-Sophia Antipolis, 2000): 185-96.

Craps, Stef. "Linking Legacies of Loss: Traumatic Histories and Cross-Cultural Empathy in Caryl Phillips's Higher Ground and The Nature of Blood," Studies in the Novel 40.1-2 (Spring-Summer 2008): 191-202.

Cruse, Harold. The Crisis of the Negro Intellectual (1967; New York: Quill, 1984).

Dabydeen, David. A Harlot's Progress (London: Jonathan Cape, 1999).

------. Hogarth's Blacks: Images of Blacks in Eighteenth Century English Art (Manchester: Manchester UP, 1987).

Donnell, Alison. Twentieth-Century Caribbean Literature: Critical Moments in Anglophone Literary History (London \& New York: Routledge, 2006).

Eckstein, Lars. "The Insistence of Voices: An Interview with Caryl Phillips" (1999), ARIEL: A Review of International English Literature 32.2 (April 2001): 33-43.

Frank, Anne. The Diary of Anne Frank (1947; London: Pan, 1974).

Gilroy, Paul. The Black Atlantic: Modernity and Double Consciousness (London \& New York: Verso, 1993).

Greene, Sue; "The Use of the Jew in West Indian Novels," World Literature Written in English 26.1 (1986) : 150-69.

Hearne, John. The Land of the Living (1961; New York: Harper \& Row, 1962).

Kincaid, Jamaica. Mr. Potter (NewYork Farrar, Straus \& Giroux, 2002).

Kowaleski Wallace, Elizabeth. "Telling Untold Stories: Philippa Gregory's A Respectable Trade and David Dabydeen's A Harlot's Progress," Novel: A Forum on Fiction 33.2 (Spring 2000): 235-52.

Ledent, Bénédicte. Caryl Phillips (Manchester: Manchester UP, 2002).

Lester, Julius. "The Outsiders: Blacks and Jews and the Soul of America," Transition 68 (Winter 1995): 66-88.

Levy, Andrea. Small Island (London: Review, 2004).

Maes-Jelinek, Hena. "Lawrence Scott's Caribbeanness: A Personal Reading of Witch-broom and Aelred's Sin," in Postcolonial Knitting: The Art of Jacqueline Bardolph, ed. Richard Corballis \& André Viola (Palmerston North: Massey University, School of English and Media Studies and CRELA, Université de Nice-Sophia Antipolis, 2000): 154-70. 
Published in The Cross-Cultural Legacy: Critical and Creative Writings in Memory of Hena Maes-Jelinek, ed. by Gordon Collier, Geoffrey V. Davis, Marc Delrez and Bénédicte Ledent (Leiden \& Boston: Brill/Rodopi, 2017), pp. 201-218.

Status: Postprint (Author's version)

-----. "'Tricksters of Heaven': Visions of Holocaust in Jonestown and Fred D'Aguiar's Bill of Rights," in Maes-Jelinek, The Labyrinth of Universality: Wilson Harris's Visionary Art of Fiction (Cross/Cultures 86; Amsterdam \& New York: Rodopi, 2006): 419-37.

Marshall, Paule. The Chosen Place, the Timeless People (1969; London: Longman, 1970).

Mihaileanu, Radu. Va, vis et deviens (Elzévir Films, Elzevir Films, France | Israel | Belgium|Italy 2005; 140 min.).

Pagnoulle, Christine. "David Dabydeen's A Harlot's Progress: Memories in Knots and Stays," in No Land No Mother: Essays on David Dabydeen, ed. Kampta Karran \& Lynne Macedo (Leeds: Peepal Tree, 2007): 181-203.

Phillips, Caryl. The Atlantic Sound (London: Faber \& Faber, 2000).

------. A Distant Shore (London: Secker \& Warburg, 2003).

------. The European Tribe (London: Faber \& Faber, 1987).

------. Foreigners: Three English Lives (London: Harvill Secker, 2007).

------. Higher Ground (London: Penguin, 1989).

------. The Nature of Blood (London: Faber \& Faber, 1997).

A New World Order (London: Secker \& Warburg, 2001).

"On 'The Nature of Blood' and the Ghost of Anne Frank," CommonQuest 3.2 (1998): 4-7.

Phillips Casteel, Sarah. "Calypso Jews: Holocaust Refugees in the Caribbean Literary Imagination," Holocaust Studies 19.2 (Autumn 2013): $1-26$.

Raiskin, Judith. "The Art of History: An Interview with Michelle Cliff," Kenyon Review 15.1 (Winter 1993): 57-71.

------. Snow on the Cane Fields: Women's Writing and Creole Subjectivity (Minneapolis \& London: U of Minnesota P, 1996).

Rothberg, Michael. Multidirectional Memory: Remembering the Holocaust in the Age of Decolonization (Stanford CA: Stanford UP, 2009).

Schamp, Jutta. "Transfiguring Black and Jewish Relations: From Ignatius Sancho's Letters and Olaudah Equiano's Interesting Narrative to David Dabydeen's A Harlot's Progress," ARIEL: A Review of International English Literature 40.4 (October 2009): 19-46.

Schatteman, Renée. "Disrupting the Master Narrative: An Interview with Caryl Phillips," Commonwealth 23.2 (Spring 2001): 93-106.

Scott, Lawrence. Aelred's Sin (London: Allison \& Busby, 1998).

-."'Extravagant Stangers': Contribution to a Round Table Discussion," in Bridges Across Chasms: Towards a Transcultural Future in Caribbean Literature, ed. Bénédicte Ledent (Liège, L3-Liège Language and Literature, 2004): 13-17.

-----. Night Calypso (London: Allison \& Busby, 2004).

Stein, Mark. "David Dabydeen talks to Mark Stein," Wasafiri 29 (Spring 1999): 27-29.

Sternberg, Claudia. "'We're Not Jews': Blending Postcolonial and Jewish Discourses in Contemporary British Literature," in Colonies, Missions, Cultures in the English-Speaking World-General and Comparative Studies, ed. Gerhard Stilz (Tubingen: Stauffenburg, 2001): 191204.

Strauss, Monica. "Caryl Phillips and the Forum on Migration: Teaching the Value of Diversity," Aufbau 6 (23 March 2000): $28-29$.

Walcott, Derek. "A Far Cry from Africa" (1962), in Walcott, Collected Poems 1948-1984 (1962; London: Faber \& Faber, 1992): 17-18.

Wideman, John Edgar. Fever (New York: Penguin, 1989).

Zierler, Wendy. '"My Holocaust Is Not Your Holocaust': 'Facing' Black and Jewish Experience in The Pawnbroker, Higher Ground and The Nature of Blood," Holocaust and Genocide Studies 18.1 (Spring 2004): 46-67. 